\title{
TDENTITY AND MEMORY IN EASTERN AND CENTRAL EUROPE: TRACING CZESŁAW MIŁOSZ AND MILAN KUNDERA
}

\section{Leonidas Donskis}

Vytautas Magnus University of Kaunas, Email: donskis@yahoo.com

\section{Acknowledgements}

This paper was presented at the Sixth international conference on Baltic and Nordic Studies in Romania Historical memory, the politics of memory and cultural identity: Romania, Scandinavia and the Baltic Sea Region in comparison, hosted by the Romanian Association for Baltic and Nordic Studies, Faculty of History and Political Sciences of Ovidius University of Constanța and International Summer School of The University of Oslo, Norway, May 22-23, 2015. Supported by EEA Grants, contract no 4/22.07.2014.

\begin{abstract}
:
Identity and memory are two indispensable keywords of society and culture when we deal with Eastern and Central Europe in terms of their modernity and its predicaments. Put in the context of politics and literature, they allow a point of departure in a study of yet another Europe, that is, Eastern Europe on the mental map of Western Europe. They serve as an important trajectory in the history of consciousness of a significant part of Europe that has yet to be tackled, grasped, and appreciated by the political, academic, and educational mainstream of Western Europe with its innumerable clichés and stereotypes over Eastern and Central Europe. No theoretical or empirical analysis would match the depths and originality of exploration of this issue which we encounter in the essayistic writings and fiction of two major Central European writers - namely, Czestaw Miłosz and Milan Kundera. This study in the history of consciousness and also in politics and literature offers an interpretive framework for a European scholarly debate on Eastern and Central European sensibilities.
\end{abstract}

\section{Rezumat:}

Identitatea și memoria reprezintă doi termeni cheie indispensabili în ceea ce privește societatea și cultura atunci când abordăm problematica Europei Centrale şi de Răsărit în termenii modernității şi aporiilor. Plasați în contextul politicii şi literaturii, aceștia oferă un punct de plecare către o altă Europă, Europa Răsăriteană, aşa cum o regăsim pe harta mentală a Europei Occidentale. Ei slujesc 
ca o traiectorie importantă în istoria conștiinței unei importante părți a Europei care este încă necesar să fie abordată, înțeleasă și apreciată de către curentele de gândire predominante din lumea politică, academică și educațională a Europei Occidentale, cu nenumăratele sale clișee și stereotipuri cu privire la Europa Centrală și de Răsărit. Nu există nicio analiză teoretică sau empirică care să egaleze în termenii profunzimii și originalității explorarea acestui subiect aşa cum apare în scrierile eseistice și de ficțiune ale celor doi mari scriitori central-europeni, Czesław Miłosz și Milan Kundera. Studiul istoriei conștiințtei și al politicii și literaturii oferă cadrul interpretativ pentru o dezbatere academică asupra sensibilităților Europei Centrale și de Răsărit.

Keywords: Communism, dystopia, identity, imagination, Ketman, memory, modernity

\section{Eastern Europe on the mental map of Western Europeans}

Ernest Gellner, in a posthumously published essay on how to rethink and write history at the end of the twentieth century, depicts the collapse of Communism as a disaster. There must be a moral order provided by a civilization. According to Gellner,

The manner of the dismantling of the Russian revolution may come to be seen as a disaster comparable only with the revolution itself. I do not wish to be misunderstood. I write as a life-long anticommunist and anti-Marxist. For a person of my age and background, I belong to what sometimes felt like a small minority of people who never passed through a Marxist phase. . . . Yet I deplore the disintegration of the Soviet Union; not because I ever sympathised with the ideology which had inspired it, but because of concerns about the need for continuity. Marxism had provided the societies under its sway with a moral order - a set of moral values which helped people to orient themselves. They knew what the rules, the idiom and the slogans were. These added up to a system you could understand and adjust to, whether or not you approved of it. An east European living under communism who confronted a person from the free world had a measure of dignity: deprived of many civil liberties, and a western standard of living, he nevertheless belonged to a rival civilisation -one which stood for something different. It had not been doing very well, by its own standards or by most others. But that had not always been obvious and no single individual had been personally dishonoured by the historic mistakes which had led to 
communism. Today, a typical east European is simply a very poor cousin. If he is an intellectual, his best prospect is temporary or permanent migration. East Europeans do not represent a failed, but important, alternative; they represent failure by the standard norms. ${ }^{1}$

Gellner's insights into the collapse of Communism shed new light on how to write and reflect on history in the age of the decline and fall of secular ideocracies. As for the political implications of his critical perspective, he extends it not only to throw new light on the failures of totalitarianism, but also to rethink what he terms "the western laissez-faire illusion." According to Gellner, totalitarianism cannot run an industrial society, but neither can pure laissez-faire. ${ }^{2}$ This is why Gellner favours a sceptical social democracy instead.

Most importantly, Gellner touches upon a sensitive issue. An American, a Brit, or a German, does not need to say a word about his or her identity, as it speaks itself with a voice of economic and political power of a given country. Yet an Eastern or East/Central European, having introduced him/herself or having been identified as one, necessarily has to switch to a historical-cultural or, more frequently, a post-Cold-War narrative telling a moving story of his or her country's belonging, albeit disrupted and arrested, to the West.

Therefore, Eastern Europeans often do not have any other option than to submit their life stories and personal details to a political or cultural history lesson about their respective country which is offered to Western Europeans. This is why they usually do not introduce themselves as fleshand-blood human beings; instead, they tell a story about their country and its heroic efforts to become presence in, and part of, the West.

In doing so, they are bound to become part of their country's historical narrative or to criticize that country in harsh terms just to be able to examine their own self-worth and to present their person. Ambiguity of their country easily allows them to improvise an identity that allegedly is deeply rooted in history and linguistic-cultural paraphernalia, as if a story teller would have no other faculty of his or her soul than exotic otherness or ambivalent and unpredictable belonging to the Western world or, more symptomatically, Western civilization. The ambivalence, ambiguity,

\footnotetext{
${ }^{1}$ Ernest Gellner, “The Rest of History," Prospect (May 1996): 34-35.

2 See ibid., 36-38.
} 
uneasiness, volatility, versatility, and unpredictability of their belonging make them have their ready-made identity stories and documented narratives at work.

The less known and the more ambiguous your country is, the longer your historical-cultural narrative becomes. You are supposed to have a strong, distinct, resilient, yet curious and exotic identity precisely because you do not belong here. The need for a strong and versatile identity springs from loosening or abandoning the sense of belonging. We allow and even encourage others to be as distant as possible when we deny them access to our ideas and politics and we want them to serve as facts or empirical evidence that would support our theories and blueprints for social and moral order.

This is to say that for a more sophisticated milieu in the West, Eastern Europeans become communist or postcommunist story tellers; in less fortunate circumstances, they serve merely as living proof of the increase of the purchasing power or social mobility of Eastern Europeans. This forced production of self-introductory and self-justificatory narrative, not to say colonization of memory and self-comprehension, is what happened to Eastern Europe on the mental map of the West in the era of liquid modernity. Things were quite different in the era of solid modernity, though.

As Larry Wolf plausibly argues, Eastern Europe emerged on the mental map of Enlightenment philosophers as a vast and largely imagined territory of chaos, ambiguity, ambivalence, backwardness, and barbarity as opposed to harmony, rationality, lucidity, and civilization emanated by Paris, France, and Europe in general. ${ }^{3}$ This sort of mental map and a curious, yet hardly accidental, trajectory of Enlightenment consciousness led Voltaire so far as to depict Russian, Polish, or Bulgarian aristocrats in his philosophical tales and plays (in Candide, Voltaire disguises Prussians as Bulgarians), although he never visited Russia or Poland. The philosophes imagined Russia and its provinces as a perfect experimental territory to try out their political ideas and projects. Jean-Jacques Rousseau attempted to draft a constitution for Poland without ever visiting the country. Denis Diderot served to the Russian Empress Katherine the Great as her chief

\footnotetext{
${ }^{3}$ See Larry Wolf, Inventing Eastern Europe: Map of Civilization on the Mind of the Enlightenment (Stanford, Calif.: Stanford University Press, 1994).
} 
librarian and mentor of philosophy. Voltaire confined his service of this kind to mentoring the Prussian Emperor Frederic the Great.

Small wonder that the French writer Prosper Mérimée, in his horror story Lokis (1869), set in Lithuania, depicts a noble who is half bear and half man and who enjoys feasting on human flesh ("lokis," or, more precise, "lokys," is the Lithuanian for bear). Incidentally, the Lithuanian noble bears the name of one of present European commissioners ("Szemiot" is the Polish for "Šemeta," or the other way around, if you will).

The Irish writer Abraham "Bram" Stoker writes, at the beautiful English town of Whitby, the vampire tale, Dracula (1897), whose main character, Count Dracula, comes from Transylvania - the name of this part Romania sounds as odd and unfamiliar to the ears of a European as that of Lithuania.

Why should we wonder, then, at the American writer Jonathan Franzen's novel, The Corrections (2001), where Lithuania is depicted as a backward and devastated country, or at Thomas Harris's crime novel, Hannibal Rising (2006), whose main character Hannibal Lecter, M.D., a psychiatrist and cannibalistic serial killer, was born in Lithuania? All these fictional stories and characters located in what appears Europe and yet not exactly Europe, or yet another Europe, allow us to arrive at the conclusion that anything can happen in Eastern Europe.

With good reason, therefore, a good part of Giacomo Casanova's adventures, as his Histoire de ma vie (1794) vividly testifies, occur in Russia. Or recall Baron Munchausen's incredible stories, penned by Rudolf Erich Raspe in The Surprising Adventures of Baron Munchausen (or Baron Münchhausen's Narrative of his Marvellous Travels, 1785), which lead us, among other places, to Livonia, that is, the Baltic lands.

However, no reason exists nowadays to describe Eastern Europe as a territory of ambiguity and ambivalence. Western Europe has lost its belief in the solid and lasting foundations of its own social and moral order. On the other side, Islam and Muslim countries are cast as the only territory of overt and covert threats, fear, and loathing. An Eastern European, if s/he happens to be an intellectual, having become a poor cousin, instead of a rival or enemy, is bound to choose between (1) parroting Western rightwing Islamophobic propaganda, or left-wing tirades against Israel and America, or (2) examining his own life and taking a moral stand, opening 
up for, and sympathizing with, those who have succeeded them as cultural/civilizational curiosities, newly produced enemies, or evil forces.

Indifference cold as ice, rather than contempt or intense loathing, is characteristic of Western Europe's attitude to present Eastern and Central Europe. Another threat to Eastern/Central European intellectuals, in terms of their marginalization or sociopolitical and sociocultural miscast, comes from their own countries where the traditional roles of intellectuals as the personification of the conscience and as the principal driving force behind the nation-building process disappeared over the past twenty years, as if those roles vanished in the air leaving no trace.

Being unable to enjoy their life and work in the truly prestigious academic institutions, as none exist or are identified and celebrated as such in the countries of incessant change and direction-free transformation, Eastern and Central European academics and intellectuals are bound to choose between shifting their roles toward the field of political power and prestige, becoming Realpolitik experts and advisers, or specialists in public relations and entertainment at home (trying to escape marginalization and poverty), and temporary or permanent migration in North American or Western European academic towns and universities.

\section{Ketman, or a world of secrecy and mental acrobatics}

Czesław Miłosz's subtle interpretation of what he terms Ketman opens up an elusive and complex phenomenon, a world of concealed identity, acting, pretending, and mental acrobatics. Ketman is a timehonoured principle of Islam, although it dates back to ancient Persian culture, and the term has its roots in the Persian language. According to Ketman, Muslims are entitled to conceal their true faith and temporarily adopt a false one in the face of grave danger to their dignity and life.

In his thoughtful and subtle analysis of the totalitarian system of brainwashing and manipulative exchanges, Miłosz offers a new interpretation of Ketman, which, in his able hands, is transformed into a trans-ideological and trans-civilizational idiom that operates equally well within religious and secular ideocracies.

Miłosz's provocative and thought-stimulating interpretation of Ketman enabled him to reveal different literary devices and interpretive techniques concealing the true political, moral, aesthetic, and religious views of oppressed people. These devices and techniques were invented or 
perfected by Central and East-European intellectuals desperately trying to survive and act decently in a world of cynical lies and severe censorship.

In The Captive Mind (1953), Czesław Miłosz analyzes the following varieties of modern ideological Ketman: National Ketman; the Ketman of Revolutionary Purity; Aesthetic Ketman; Professional Ketman; Sceptical Ketman; Metaphysical Ketman; and Ethical Ketman. Oddly enough, the phenomenon of Ketman was discovered and described by the founding father of racist anthropology, Comte Joseph Arthur de Gobineau, a perceptive yet dangerous writer, whose book, Religions et philosophie dans l'Asie Centrale (1865), made this European social determinism and racism available to a nineteenth-century readership.

Having described the cases of Hadzhi-Sheikh-Ahmed, the founder of a sect in Persia, and Sadra, the disciple of Ibn Sina (Avicenna), Gobineau recalled his revealing conversation with a Persian who admitted that not a single true Muslim could be found in Persia. This led Gobineau to assert that Ketman was a widespread phenomenon and was practiced almost universally in Persia. Describing this mysterious phenomenon, Gobineau emphasized the enormous pleasure and intellectual satisfaction of those who were intelligent, daring, and cunning enough to liberate themselves from the chains of ideocratic community and to cheat the deeply oppressive system of thought and action, secretly practicing their faith or philosophy. Gobineau devotes much of his attention to the ability of those who practice Ketman to keep on their guard in the darkness of illusion and ignorance.

But Ketman is a mortally dangerous mental and intellectual acrobatics. Just a minor diversion or logical mistake, and you are exposed. Then nothing would save you from death. As a technique of misleading your opponent or enemy, Ketman takes much time, energy, and vigilance. Sadra, for instance, had to fake his piety, deep religiosity, and his absolute obedience to the mullahs, until the mullahs exempted or softened their control, having no doubts about his dedication.

Only then, according to Gobineau, was Sadra able to figure out, through a painstaking study of faces, spontaneous reactions, and the comments of those who attended the meetings, who was prepared for the truth. Having examined his audience carefully, having established an elusive contact with it, and having achieved silent reciprocity, elusive 
solidarity, and empathic relationship, Sadra decided to unmask and show himself the logician and metaphysician that he was.

Ketman is by no means an exclusively Islamic phenomenon. An intercivilizational idiom of, and a symbolic reference to, the surrender to an alien dogma while practicing secretly your religion or culture, one or another form of Ketman accompanies nearly every clash of ideas, doctrines, and ideologies throughout history. Thus, consider the Nicodemites in the Roman Empire who were concealed Christians. Seneca was thought by some Renaissance humanists to have been a Nicodemite. Another example would be the Marranos in fifteenth-century Spain. Those crypto-Jews converted to Christianity yet practiced Judaism secretly.

Ketman must have always existed, in myriad ways, wherever philosophy was regarded as a blasphemy, diversion, and crime, and wherever heterodoxy was not tolerated. In a way, Ketman was a preheretical and pre-heterodox form of dissent, which survived into the twentieth century as a form of covert political dissent. An abortive form of dissent, Ketman proved capable of entering any civilization and adjusting to secular ideocracies too.

\section{The Ketman of philosophy}

Countless logical and metaphysical games of medieval philosophy, invented with the sole purpose of appeasing the oppressive and allembracing system of thought and action to make the existence of autonomous thought possible, fall into that same category. Monotheism, in its rise and in its most furious phases, hardly allows room for philosophy as a truly independent intellectual activity. Instead, the pre-modern forms of monotheist religions allow a narrow framework for answering logical and theological questions, and reducing philosophy to a secondary intellectual enterprise.

This is true of every monotheist religion unless it is reconciled with modern life and thought. In an oppressive and self-contained value-andidea system where apostasy, heterodoxy, and dissent are not tolerated, philosophy survives either as a Ketman or as a half-concealed esoteric practice. The same might be said about pre-modern monotheistic civilizations. As the acceptance of an alien dogma while you practice your religion secretly or keep fidelity to your values, Ketman probably originated as a trans-civilizational phenomenon, instead of something 
reducible to Islam or the Stalinist phase of Communism. By and large, the history of philosophy is a history of Ketman, as far as the premodern civilizational forms of monotheism are concerned.

Whether we like it or not, the truth is that epochs, centuries, and phases of civilizations in world history were blank pages in the history of philosophy. Only the ancients, or, to paraphrase David Hume, the tolerant idolaters and the moderns were able to practice philosophy with no risk to their lives. Neither Islam nor Judaism allowed room for autonomous philosophy. Philosophy could survive there only through esoteric and mystical tradition, itself a refined and sublime form of Ketman. Early and medieval Christianity was not a haven for autonomous theoretical thought either. Therefore, a study of the fate of philosophy in Western and nonWestern civilizations is especially instructive when dealing with such issues as tolerance, ideocracy, and Ketman. For Christian civilization of the West to develop what we now call the theoretical and moral foundations of tolerance and pluralism took centuries.

Czesław Miłosz's conception of Ketman practiced in East-Central Europe as the last resort of human dignity and safety rests on his assumption that people in the Soviet Union and in the people's democracies were able to survive and give some meaning to their lives only through acting. Through acting and simulating fidelity or faking loyalty, many people survived the regime, especially in its most furious phases, such as the Stalinist purges. Many people realized instantly that the only rescue was to fabricate their personality and then fake their emotions and reactions. The only way to survive was to fake your mental life. According to Miłosz,

It is hard to define the type of relationship that prevails between people in the East otherwise than as acting, with the exception that one does not perform on a theater stage but in the street, office, factory, meeting hall, or even the room one lives in. Such acting is a highly developed craft that places a premium upon mental alertness. Before it leaves the lips, every word must be evaluated as to its consequences. A smile that appears at the wrong moment, a glance that is not all it should be can occasion dangerous suspicions and accusations. Even one's gestures, tone of voice, or preference for 
certain kinds of neckties are interpreted as signs of one's political tendencies. ${ }^{4}$

Such a world of permanent acting and danger creates the atmosphere of alertness. It sharpens the intellect and troubles the moral imagination. To eliminate the slightest possibility of being open to the charge of treason, you have to forge a new vocabulary of morals, politics, and culture. If you can imagine the collapse of the Centre and the dissolution of the New Faith, you must have a strong argument at hand to justify your former involvement in the System, in order not to be exposed as a fool or cynical opportunist.

\section{Czesław Miłosz's model of identity}

Czesław Miłosz's legacy still challenges us posing a number of pivotal questions revolving around the nexus of East-Central European political existence, and also identity and memory politics. Is assimilation into another society, which involves acquiring an accent in due course, and possibly even losing native language, such a tragedy and a sin if a human being, despite it all, preserves deep links with the homeland, remains interested in its culture and is empathetically open in his/her soul and mind to the country's contemporary reality, and even supports it politically and morally?

In what way is a human being better when he or she mechanically learns his/her parents language, though is formed by another culture: and in his or her thoughts and lifestyle remains fundamentally foreign to the country and culture of his or her parents?

Is not more important to preserve one's native language and national identity, at the same time participating in the life and culture of the country in which we are living? Can it really be that an ascetic cultivation of national community values that completely ignore the country in which one lives is the best way to preserve one's culture, or one's intellectual, critical, and creative strength?

Is active participation in international academic culture in any way sinful? Can it be sinful to enter the intellectual territory of the largest European languages that opens up a true dialogue as well as the possibility for an understanding of one's self and culture?

\footnotetext{
${ }^{4}$ Czesław Miłosz, The Captive Mind (New York: Vintage Books, 1990), 54.
} 
On the other hand, should we consider the greatest value to be the preservation of one's native language even in the case when the person using the language provokes feelings of shame in us, as representatives of the same language and culture, due to his/her views and rhetoric? If this person has committed a crime against humanity and, in this way, demeaned his/her nation as a collective individual, as a historical actor, and, to use Johann Gottfried von Herder's and Peter Chaadayev's concept, a moral entity?

Why should a human being who has preserved his or her Lithuanian language, but rejected the values of Western civilization and chosen modern barbarity, be in any way more valuable than the one who does not speak the native language of the parents and the grandparents, but is intensively seeking a link between Lithuanian and other modern forms of sensitivity and his/her inner self and the world? Should we feel betrayed and ashamed because Alphonso Lingis, a noted American philosopher of Lithuanian background, does not write in Lithuanian?

Was Czesław Miłosz any less important to us because he did not speak and write in Lithuanian? Unfortunately, these are not rhetorical questions. If we hold intellectual and moral sensitivity as being less important than knowing the native language for the basis of what a Lithuanian is, then we will never be able to return Miłosz or the Litvaks to our culture.

National faithfulness can find expression not only by an unconditional loyalty to our community and a defence of its historic and contemporary reputation, but also via dissent from the dominant tendencies in our society and culture, which contradict or even reject universally accepted moral norms, codes of behaviour, manners of expression, and even entire trajectories of consciousness.

Faithfulness to humanism or to any other moral culture that defends human dignity, respect for human life, and the principle of the incomparable value of an individual and his or her culture, in the end, also means moral faithfulness to our nation, community, and culture.

Dissent from the deformations of one's culture, which today are felt by others but which tomorrow we will inevitably experience ourselves or will be experienced by other generations, just as vociferous protest against one's country's amoral politics, is a higher form of faithfulness to one's country. In that it connects the moral commitment to humankind with a 
trust in our society and culture, which is held as being able to maintain universally humane norms.

Otherwise, the xenophobes, who rail against Jews, Poles, or Russians, and cynics, who apply double standards to their "own kind" as opposed to their ideological opponents or minorities, who are ready at any moment to betray their state or to strive for power and prestige at the expense of their society's civic solidarity or their country's wellbeing and international reputation (what we have been witnessing in today's Lithuania), may appear to be somehow more "true homeland types," than those Jews, Poles, or Russians, who are loyal to Lithuania and are, to the depths of their souls, attached to the landscape and mainstream culture of Lithuania.

Just as the unconditional defence of one's self and one's people from criticism of foreigners can seem to us nobler than criticism of our society and culture, disagreeing with what is considered to be a threat to our own moral character and our person, regardless of what kind(s) of mask(s) of devotion to Lithuania camouflage those deformations.

Contemporary society's human identity is multidimensional and pierces at least several layers of cultural and social experience. It is not for nothing that Vytautas Kavolis wrote so much about the postmodern identity (but by no means did he hold postmodernism to be identical with anonymous fashions, relativistic codes of moral culture, new cultural taboos, cult representatives and movements - instead, he treated postmodernism first of all as an attempt to bridge what was cleaved off by modernity, joining modernism and antimodernism in our consciousness and culture).

Kavolis understood the postmodern identity as a link of multidimensional layers that inter-communicated, and perhaps even as an intensive polylogue among them - as a Czesław Miłosz-type devotion to one's culture, but, at the same time, preserving empathy and openmindedness to other societies and cultures. ${ }^{5}$

For Lithuania in the twenty-first century, Miłosz's model of identity will truly be important, not that of politically out-of-date and morally worn-out conservative nationalists.

\footnotetext{
5 See Vytautas Kavolis, "Nationalism, Modernization, and the Polylogue of Civilizations," Comparative Civilizations Review 25 (Fall 1991): 136.
} 


\section{Memory politics: remembering vs. forgetting}

The conservative imagination is tragic and pessimistic, while the liberal imagination reveals itself and the world around us in a more playful, optimistic, and ironic fashion. Tragedy remains the essence of the conservative imagination, whereas the liberal imagination is best represented by laughter.

In The Book of Laughter and Forgetting, Milan Kundera describes Gustav Husak as the President of Forgetting who needs the forms of aesthetic and political Kitsch and mass culture as potent instruments of organized forgetting. After 1968, Husak refuses to take seriously a mass emigration of Czech and Slovakian writers, composers, film directors, scholars, and medical doctors, yet he immediately reacts to the emigration of a pop music star, Klaus. Husak writes a friendly and warm letter to the pop music singer, asking him to return to Czechoslovakia and promising him heaven on earth. Never mind that an exodus of the intelligentsia deprived the country of its intellectual and artistic potential; but the emigration of a music idiot is a tragedy, for Husak understands that they can work hand in hand to jointly and efficiently rob Czechoslovakia of its memory and history. They need each other. The President of Forgetting and the Music Idiot work for the same cause.

In the winter of the year 1948 the Czech Communist Party leader Klement Gottwald and his comrade Vladimír Clementis stand ready for a solemn speech in an historic building without being aware that this was the German gymnasium where Franz Kafka studied. They would never suspect that Kafka's father had a store on the ground floor of the building where a jackdaw was depicted on the wall. "Kavka" is the Czech for jackdaw. In four years, Clementis, who kindly offers his hat to Gottwald to protect a comrade from freezing, will be hanged for the alleged coup, and his image will be eliminated from all photographs. All that remains of Clementis is the cap on Gottwald's head. The same applies to Clementis's place in political memory manufactured by the régime: he is merely a miserable traitor whose face is unworthy to remember, and whose name must sink into oblivion.

Kundera ascribes the fatal forgetting to the city of Prague. Prague appears in Franz Kafka's The Trial (1925) as a city devoid of memory and self-comprehension. The real Prague is entangled in the same frame of mind. It constantly changes the names of its streets, forging the city's life as 
a never-ending present and obliterating every trace of the past. In doing so, the city turns into a memory-free ghost, a creature of anonymous mass society, and a non-entity. The Counter-Reformation did this by changing the names of Prague's streets and creating the illusion that real history will start anon. In the twentieth century, Prague was forced to believe that up to now its history was a fraud, and that History with a capital $\mathrm{H}$ now creates new names and narratives.

However, to lightly equate remembering with authentic existence, and forgetting with the obliteration of self or the denial of the world, is the last thing a serious writer would do. Too much memory can destroy human life, as Kundera convincingly shows by depicting the novel's heroine Tamina, a young and beautiful widow who is unable to build a second life in France. Tamina is unable to establish any lasting emotional and social intimacy with a small French town's milieu. She does not belong there. Mentally, Tamina continues living elsewhere. She is incapable of restoring her powers of association and ability to forget, two indispensable conditions of the will-to-life.

Tamina is separated from her intimacy and memory, since all of her letters are left in Prague. Little chance exists that her love letters and diaries remained unread by her relatives or, worse, un-scrutinized by the régime. In a desperate attempt to keep in touch with her family members and to recover her letters, Tamina engages in an empty and meaningless affair with a young Frenchman only to be able to make expensive long-distance telephone calls to Prague from his apartment. The divorce of the present and the past does not offer any way out of this predicament. Tamina is doomed to failure. Too much memory becomes the unbearable burden depriving her of the meaning of existence and forcing her to take her life.

In Kundera's novel, The Unbearable Lightness of Being, the heroine Teresa becomes vulnerable and fragile because of her failure to forget the traumatizing experience with her mother. It is hardly accidental that, in addition to Kafka and Kundera, one more major Central European writer, Robert Musil, depicts a man without qualities in his novel of similar title, The Man without Qualities (1930-1942). The anonymity, facelessness, Angst, anguish, solitude, isolation, and despair of the cornered individual come out in Musil's novel as the unavoidable signs and manifestations of the destructive powers of modernity with all of its obsessive fixations on the 
liberation of individuals from their legacy, past, and inherited parts of identity.

The destructive powers of modernity would be unthinkable without forgetting the past, a crucial aspect of modernity's obsessive belief in the future. That dying individuals lose their past rather than the present and the future we learn from the unbearably light and ironic Kundera, but not from the deadly serious prophets of modernity. Yet the politics of remembering is not the way out of the uncertainties and painful dilemmas of modernity. It works well as a remedy from the malaise of forgetting, oblivion, and insensitivity, as long as it serves as a framework for dissenting thought and stance. The politics of remembering begins in a prescriptive mode of self-comprehension; however, it can turn into a dangerous fixation on selected series of events and historical personalities that would result in the total denial of those individuals and groups that remember in a different fashion.

The politics of remembering is sound and good only insofar as we maintain the legitimacy of two or more opposed modes of memory and narrative. The legitimacy of two opposed interpretations of the same phenomenon, including political experience, is what modernity with a human face is all about. A happy and unforced equilibrium of remembering and forgetting appears as the natural condition of our life. The politics of remembering, if forced and practiced with no alternative to it, will unavoidably be at the peril of becoming an oppressive instrument of arbitrary and selective memory. Such a memory work can serve as the denial of others and their right to experience and remember the world in the way they want. Competing memories and opposed narratives are characteristic of warring nationalisms, especially when they clash in multiethnic, multi-religious, and multi-cultural cities.

In fact, the politics of remembering reveals the past as a critical aspect of our experience, as something without which we could never sustain our political and moral sensibilities. Yet when it becomes the axis of political life, we can slide into the tyranny of a frozen time that divides the world into "us" and "them". In doing so, we are at the risk of adopting the Manichaean moral logic that does not allow us to grasp social reality as consisting of flesh-and-blood human beings able to change their views, convictions, and stances. The tyranny of the past would never allow us to 
reconcile ourselves with the world, especially when peace with the former political foe and oppressor is at issue.

Nothing is simple and obvious here, for the dialectic of forgetting and forgiving is one of the most complex of all human experiences. To regard all Germans as crypto-Nazis and anti-Semites, or at least as covert sympathizers of National Socialism, would be barbarous, as would taking all Russians to be natural-born totalitarians and imperialists. We have to suspend the details of our martyrdom and to overcome the temptations of comparative martyrology not to contaminate present forms of life with hatred.

This effort implies a methodical forgetting, which is reminiscent of suspending or putting aside what does not help to deal with present social and political reality. Such an effort does not signify the repression of our memory or the arrival of a mental self-censorship. Contrary to widespread opinion, the politics of forgetting does not necessarily imply the destructiveness of modern life with totalitarian régimes, devaluation of life, insensitivity, and social constructivism. Sometimes, forgetting lends itself to forgiveness, liberating us from the burden of worn-out concepts and arguments. Like remembering, forgetting is at its best when it comes as an existential and moral choice. Forgetting cannot be an imposed action, which surfaces, leaving unresolved tensions, animosities, and hatred underneath. This is to say that remembering and forgetting have to encompass each other as two complementary forms of grasping life and as two intertwined ways of looking at the world around us.

According to Kundera, if human beings were able to remember everything they would become totally self-contained and self-sufficient, and, in effect, would end up with dramatically diminished powers of association. Modernity is obsessed with controlling memory and rewriting history in accordance with power distribution or disposition. I am in control of societal existence and culture; therefore, I am able to provide a legitimizing narrative. Memory is an aspect of power. What and how to remember and what and how to forget depends on who writes an account of an epoch's history and political deeds.

To memorize and keep everything for the generations to come, prolonging the existence of, and giving a second life to, those who deserve it? I remember, therefore, I am? Or to forget what is irrational and does not qualify for the realm of collective memory? These are two opposed, if not 
mutually exclusive, promises of modernity. We know that all three of the greatest authors of twentieth-century dystopias, Yevgeny Zamyatin, Aldous Huxley, and George Orwell, prophesied the arrival of a social and political catastrophe resulting from the logic of modernity pushed to the limit. This is to say that they depicted a radical version of modernity running up against its ultimate barrier. Using literary techniques and devices, Zamyatin's We, Huxley's Brave New World, and Orwell's 1984 seek what such twentieth-century thinkers as Hannah Arendt, Simone Weil, Lewis Mumford, Isaiah Berlin, and Leszek Kolakowski sought in their social and political philosophy. In its much earlier anticipation of totalitarianism, literature overtakes theory. Literature offers a deeper presentiment of modernity's dangers.

Zamyatin, whose novel We (1924), markedly influenced Huxley's Brave New World (1932) and Orwell's 1984 (1949), portrayed transparent glass houses in which the inhabitants of the Only State were required to live and be constantly seen. This novel, a half century before Michel Foucault's "panopticon" theory appeared in Discipline and Punish, revealed modernity to be the incarnation of the obsession with unlimited power and unrestricted control. Zamyatin describes this obsession as the observation without a response and as a perfectly developed discourse of power. The asymmetry of power lies in the elusive authorities' ability to deprive us of our privacy and to make us act as if we were under surveillance all the time. To cut a convoluted and long story short, Zamyatin preceded and anticipated what the French poststructuralist, historian of consciousness, and political theorist Michel Foucault was to achieve through his complex and multidimensional theory.

Doubt may arise about chastising authors, especially Zamyatin and Orwell, as having been allied with the conservative imagination. These writers were openly leftist in their political views and attacked modernity more as a basic foundational structure of economic, social, and political existence. The essential institutional manifestation and at the same time the sociological hypostasis of modernity is capitalism. Yet the criticism of modernity of these authors, when we set aside their political views and biographies and then analyze the texts themselves, is notably conservative and proffers forms of the recognition and interpretation of reality which would be held by just about any conservative writer or thinker. 
All three of those authors of great dystopias portray the death of the institution of family. Orwell reveals its degradation, while Zamyatin and Huxley its utter disappearance. But they object to the annihilation of love. The love story of Winston Smith and Julia in 1984 is a final desperate human and social attempt to stave off the depersonalizing and dehumanizing machine of totalitarian control. This effort fails, just as the love between the narrator D-503 and the dissident I-330 in Zamyatin's We fails. The narrator's love, sociability, and powers of association are cut from under him by the régime. We and Brave New World reveal a reality in which love and the family cease to exist. Only sex, unrestrained by the state, remains. In Orwell's novel, even sex starts to degrade because the Party is powerless to destroy the orgasm, over which it has no control. As we learn from Winston and Julia's dialogues, sex in Oceania is reduced to mere multiplication, although this does not apply to the Inner Party with whose members Julia has had secret affairs. The three dystopias describe the elimination of privacy, which means a veritable triumph of the state organs of control. This obvious threat posed by present-day modernity, that was to be flagged in studies by Jürgen Habermas and Zygmunt Bauman, was foreseen by writers of dystopias.

Modernity seeks to control our memory and language in their entirety. Winston Smith attempts to recall a cherished boyhood song, which is taken over and finished by the character O'Brian, an alleged friend and brother in arms of Winston in the holy cause of resistance to the régime who turns out to be a high-ranking official in the Inner Party. Oceania, in which Orwell's book creates a new language, the New Speak, is supposed to become a place where human perception and understanding of space and time would be totally transformed. With this language, nobody would be able to understand Shakespeare. This means that the reality represented in the classical literary imagination would become unrecognizable. Radically changing everyone's field of reference and system of concepts will make easy to take away from them the dimension of the past. And by taking over their field of reference and system of concepts, humanity's history can be firmly taken over in the manner required by the collective solipsism professed by Big Brother and the Party.

We speaks to the death of the classical and the death of the past. In the Only State's education system, classical studies no longer exist, and the humanities in general disappear. Regarding the death of humanism and the 
prohibition of the study of history and classics in the education of the world of the future, the French writer Sébastien Mercier, in 1770, had first written about and given form to the extremes of the ideology of neverending progress in his work of political fantasy, L'an 2440 (The Year 2440). ${ }^{6}$ In Zamyatin's dystopia, the past is associated with barbarians whose primitive works, threatening rationality and progress, cannot be studied, while the worst illness in the Only State is what the ancient Greeks referred to as the soul. Therefore, in the context of the dystopias of Zamyatin, Huxley, and Orwell, the compound phrase "technocratic totalitarianism" would be a pleonasm, since no other form of totalitarianism seemed possible to them.

The disappearance of other important spheres discussed by these dystopias is private space, private property, which is torn out by its root, and our favorite belongings. Winston reminisces constantly about his favorite possessions, which are a part of his world and his human identity. Michael Walzer points out that it is for Winston's lower middle-class sentimentality and attachment to things, and not for his ideas, that Orwell was criticized mercilessly by Raymond Williams and other intellectuals of England's Left. Such intellectuals were unable to forgive Orwell for bestowing Churchill's first name on his novel's protagonist.

We can reject any residual doubts about Orwell's conservative sentiments, which were never incorporated into the realm of his political views and evaluations. Unlike the majority of English socialists, Orwell held patriotism to be a value and would have agreed with Simone Weil's reality of rootedness, as developed in her work, L'Enracinement (The Need for Roots, 1949). ${ }^{7}$ Like Weil, Orwell was convinced that our rootedness in this-worldly reality of community life, locality, and attachment to the past is a crucial fact of life and an existential need. That we lose the past rather than the future when we die was sensed by Orwell long before Milan Kundera made this insight the thread of The Book of Laughter and Forgetting (1979). Curiously, Kundera strongly disliked Orwell's 1984, describing it as a bad novel that, according to Kundera, misrepresented human existence, dangerously reducing it to politics. ${ }^{8}$

\footnotetext{
6 See J. B. Bury, The Idea of Progress: An Inquiry into Its Origin and Growth (New York: Dover Publications, 1987), 192-201

7 Simone Weil, The Need for Roots: Prelude to a Declaration of Duties towards Mankind (London \& New York: Routledge, 1996).

8 see Milan Kundera, Testaments Betrayed (London: Faber and Faber, 1995), 225
} 
What kind of imagination constructs utopias and dystopias? To come up with an overarching answer is difficult. This is a form of imagination where plots dictated liberal, conservative, and socialist thought and sensibility. Yet utopias and dystopias would never have been born without the conservative trajectory of this form of imagination, and without the conservative sensibility which lurks in the modern moral imagination. Yevgeny Zamyatin's We, George Orwell's 1984, and Aldous Huxley's Brave New World depict a memory-free world deprived of public historical archives and the humanities in general, just like Mercier's The Year 2440 presents the world of the future where no room exists for history. The study and teaching of history is abandoned in twenty-fifth-century France, since to study a series of human follies and irrational actions is a disgrace. How on earth can a rational human being study the past deeply permeated by superstition and backwardness?

In the philosophical implications of Kundera's literature, history appears as a meaningful and silent moral alternative to the brutality of geopolitics and power politics carried out by the powerful. Memory becomes a tool of the small and weak, while forgetting best serves the interests of the big and mighty. In this way, memory manifests itself as an alternative moral imagination in opposition to the logic of power. Memory of the powerful is nothing more than a celebration of successful practice, in the sense of Niccolò Machiavelli's concept of verità effettuale. Memory is a practice, instead of an elusive human ability or potential.

Yet this thread of Kundera's thought does not exhaust his understanding of how memory works in the modern world. What Kundera implies is that memory uncovers its essence as a conscious effort to continue or prolong the existence of what deserves to exist. Therefore, the cultural canon is a mode of the existence of organized memory. Within the framework of organized memory, Shakespeare, Van Dyck, Hals, Vermeer, or Rembrandt, depicting, portraying, or else individualizing their contemporaries, become part of the process of a conscious continuation of someone else's existence. 


\section{References:}

Bury, J. B. The Idea of Progress: An Inquiry into Its Origin and Growth. New York: Dover Publications, 1987.

Gellner, Ernest. “The Rest of History.” Prospect (May 1996): 34-35.

Kavolis, Vytautas. "Nationalism, Modernization, and the Polylogue of Civilizations." Comparative Civilizations Review 25 (Fall 1991).

Kundera, Milan. Testaments Betrayed. London: Faber and Faber, 1995.

Miłosz, Czesław. The Captive Mind. New York: Vintage Books, 1990.

Weil, Simone. The Need for Roots: Prelude to a Declaration of Duties towards Mankind. London \& New York: Routledge, 1996.

Wolf, Larry. Inventing Eastern Europe: Map of Civilization on the Mind of the Enlightenment. Stanford, Calif.: Stanford University Press, 1994. 